\title{
The Effects of L-Glutamate, AMPA, Quisqualate, and Kainate on Retinal Horizontal Cells Depend on Adaptational State: Implications for Rod-Cone Interactions
}

\author{
David Križaj,' Abram Akopian, ${ }^{2}$ and Paul Witkovsky, ${ }^{1,2}$ \\ 'Department of Physiology and Biophysics and '2Department of Ophthalmology, New York University Medical Center, \\ New York, New York 10016
}

We studied the responses of isolated and intact luminositytype horizontal cells (L-HC) in the Xenopus retina to L-glutamate (L-glu) and its analogs. Isolated L-HCs studied with whole-cell patch clamp responded to L-glu, kainate (KA), AMPA, or quisqualate (quis) with inward currents from a holding potential of $-60 \mathrm{mV}$, associated with a conductance increase. The current elicited by KA was relatively large and sustained, whereas AMPA or quis evoked a desensitizing current. Coapplication of quis and KA resulted in a smaller current and conductance change than that evoked by a pulse of either alone at the same concentration. This finding suggests that the L-HC has a single subtype of glutamate receptor that responds to both quis and KA. Prior exposure to dopamine enhanced the KA-evoked current about twofold.

In the superfused eyecup we found that L-HC responses to quinoxalinediones (CNQX or DNQX) and to L-glu, KA, AMPA, and quis varied as a function of adaptational state. When driven exclusively by either cones or by rods, CNQX/DNQX hyperpolarized the L-HC and reduced its light response, without altering response kinetics, indicating that both rods and cones communicate with L-HCs at ionotropic glutamatergic synapses. Under mesopic conditions, however, as CNQX or DNQX reduced cone input, the rod input to the L-HC increased up to fivefold in magnitude and had slowed kinetics.

The depolarizing response of the L-HC to L-glu, AMPA, or quis was relatively small and transient under photopic conditions, but was much larger and sustained when the eyecup was dark adapted. The D1 dopamine antagonist SCH 23390 potentiated the response to quis. In contrast, responses to KA were largest in light-adapted eyecups, were potentiated by a D1 dopamine agonist, SKF 38393, and were reduced by SCH 23390.

We hypothesize that the segregated populations of glutamate receptors in the L-HC opposite cone and rod synaptic endings can be separately modulated to respond differentially to the native transmitter, glutamate. In photopic and

\footnotetext{
Received Sept. 14, 1993; revised Mar. 1, 1994; accepted Mar. 24, 1994.

This work was supportcd by Grant EY 03570 to P.W., Core Grant EY 01842, and an unrestricted grant from Research to Prevent Blindness, Inc., to the Department of Ophthalmology, NYU Medical Center. We thank Drs. David Copenhagen and Daniel Tranchina for useful comments and criticisms.

Correspondence should be addressed to Dr. Paul Witkovsky, Department of Ophthalmology, New York University Medical Center, 550 First Avenue, New York, NY 10016

Copyright (C) 1994 Society for Neuroscience $0270-6474 / 94 / 145661-11 \$ 05.00 / 0$
}

mesopic states the dominant cone input tonically inhibits rod to L-HC communication. This inhibition appears to occur at the postsynaptic membrane and may be mediated by second messengers.

[Key words: horizontal cell, rod, cone, dopamine, AMPA, glutamate, quisqualate, kainatel

Rod-cone interactions are a fundamental aspect of retinal function well documented in human vision. For example, Alexander and Fishman (1984) found that the threshold of a dim red light falling on parafoveal retina was lowered in the presence of a green background field that desensitized rods. Conversely, activation of the cone system inhibits signal transfer in rod circuits. For exampie, rod input to second-order cells is diminished when dark-adapted cone signals are enhanced by dopamine (Witkovsky et al., 1988a, 1989). The general conclusion from studies of this sort is that rods somehow inhibit the flow of information through cone-connected circuitry, and vice versa. Support for this supposition comes from intracellular studies showing that the inhibitory interactions between rod and cone pathways begin at the first level of synaptic processing, that is, between photoreceptors and the second-order neurons to which they connect, bipolar and horizontal cells (Frumkes and Eysteinsson, 1987; Witkovsky et al., 1988a, 1989; Eysteinsson and Frumkes, 1989).

It is now generally accepted that both cone and rod photoreceptors utilize glutamate as a transmitter (Lasater and Dowling, 1982; Copenhagen and Jahr, 1989; O’Dcll, 1989; Ayoub et al., 1989; Marc et al., 1990). Glutamate acts through a variety of postsynaptic receptors (Mayer and Westbrook, 1987) of which retinal horizontal cells possess, at least, receptors of the AMPAkainate subtype (Massey, 1989; Gasic and Hollmann, 1992). Horizontal cells of the catfish retina also are sensitive to NMDA (O'Dell and Christensen, 1989b) and may be modulated via an AP-4 receptor (Takahashi and Cupenhagen, 1992). Moreover, Knapp and Dowling (1987) found, in fish horizontal cells, that current flow through a kainate-gated channel was increased by dopamine acting through a D1 receptor.

Collectively, these studies point out a number of possible mechanisms whereby glutamatergic transmission at the photoreceptor synapse may be modulated, but there still is no consensus about whether such mechanisms underlie the evident kinetic differences between rod and cone transmission (Schnapf and Copenhagen, 1982; Stone and Witkovsky, 1984; Kim and Miller, 1991). In an earlier study (Witkovsky et al., 1989) we elaborated an equivalent circuit model of the horizontal cell terminal dendrite whose branches enter both rod and cone bases. 
The conductance of the cone to horizontal cell synaptic battery was increased by dopamine, providing a variable shunt of rod to horizontal cell synaptic transfer. This circuit provided a basis for understanding changes in the magnitude, but not in the kinetics of horizontal cell light-evoked responses related to adaptational changes affecting rod-cone balance.

In the present study we compared data from experiments on isolated horizontal cells with responses of horizontal cells in eyecup preparations. The former data set shows that, in isolated horizontal cells of the Xenopus retina, glutamate, kainate, AMPA, and quisqualate, but not NMDA, gate membrane currents. Quisqualate- and kainate-induced currents were found to be nonadditive. Currents elicited by kainate were enhanced by dopamine. The eyecup experiments demonstrated that the effects of kainate and L-glu, AMPA, or quisqualate on the horizontal cell membrane potential and light-evoked responses were influenced in opposite directions by the state of adaptation of the retina, and by selective Dl dopamine agonists or antagonists.

Based on these data, we postulate that the glutamate receptors in the L-HC opposite rods and cones are modifiable. Dopamine, working through cAMP, helps control the magnitude and kinetics of glutamate-gated responses by influencing the state of the glutamate receptors. In our scheme, intracellular second messenger systems located in a second order neuron assume an important role in regulating the flow of rod and cone information in the retinal network. The union of traditional mechanisms represented by synaptic batteries and resistors and intracellular modulation of synaptic signals provide a new framework for interpreting the mutual inhibition of rod and cone circuits in the distal retina.

\section{Materials and Methods}

Adult male Xenopus laevis were obtained from NASCO (Ft. Atkinson, WI) and kept in an aerated aquarium on a $12 \mathrm{hr}$ light $/ 12 \mathrm{hr}$ dark cycle with lights on at 6 A.M. Animals were anesthetized with a $25 \mathrm{mg}$ subcutaneous injection of ethyl- $m$-aminobenzoate (Sigma, St. Louis, $\mathrm{MO}$ ) in $0.2 \mathrm{cc}$ of Ringer's. Eyecups were prepared in the late morning under bright white light to ensure that the preparation was well light adapted. One eye was enucleated, hemisected and the lens removed. The posterior pole was flattened by six radial cuts in the sclera and the eyecup pinned to the wax base of a chamber through which the superfusate flowed at $1.5 \mathrm{ml} / \mathrm{min}$. We utilized a bicarbonate Ringer's (Stone and Witkovsky, 1984), supplemented with $200 \mu \mathrm{M}$ ascorbate and 200 $\mu \mathrm{M}$ thiourea. The solution was bubbled continuously with $95 \% \mathrm{O}_{2}, 5 \%$ $\mathrm{CO}_{2}$ to a final $\mathrm{pH}$ of 7.4 in the flask. A remote controlled solenoid valve (General Valve Corp, Fairfield, NJ) permitted switching between control and test solutions.

Dopamine and L-glutamate were obtained from Sigma (St. Louis, MO); SCH 23390, SKF 38393, quisqualate, kainate, 6-cyano-7-nitroquinoxaline-2,3-dione (CNQX), 6,7-dinitroquinoxaline-2,3-dione (DNQX), trans-(1S,3R)-1-amino-1,3-cyclopentanedicarboxylic acid (trans-ACPD), and ( \pm )-2-amino-3-phosphonoproprionic acid (AP-3), from Research Biochemicals Int. (Natick, MA); and $\alpha$-amino-3-hydroxy-5-methyl-4-isoxazoleproprionic acid (AMPA), from Tocris Neuramin (Bristol, UK).

Intracellular recordings were made in a standard manner with micropipettes filled with $4 \mathrm{M}$ potassium acetate, having resistances of 100$150 \mathrm{M} \Omega$. Signals were stored on digital tape for off-line analysis, using VIEWDAC (Keithley Instruments, Taunton, MA) and SPIKE (Modular Instruments, Malvern, PA) software. Light stimuli were provided by a two-channel photostimulator (Dowling and Ripps, 1972). All stimuli illuminated the retina diffusely and quantal fluxes in the plane of the retina were measured with a calibrated photodiode. Quantal fluxes are given in the figure legends as $\log Q=\log$ quanta incident $\mathrm{cm}^{-2} \mathrm{sec}^{-1}$

To obtain cells in short-term culture, retinas were stripped from hemisected eyecups, cut into two or three pieces, and incubated for $5 \mathrm{~min}$ in a Ca-Mg free, HEPES-buffered Ringer's at pH 7.1. Retinal pieces were transferred to $20 \mathrm{ml}$ of normal HEPES Ringer's, $\mathrm{pH} 7.1$, containing
$15 \mathrm{U}$ of papain/ml and $12 \mathrm{mg}$ of cysteine, for $1 \mathrm{hr}$ at room temperature on a rotating table $(60 \mathrm{rpm})$. The pieces then were washed $5 \times 5 \mathrm{~min}$ in Ringer's containing $0.1 \mathrm{mg} / \mathrm{ml} \mathrm{BSA}$ and after a final $5 \mathrm{~min}$ rinse in Leibovitz's L-15 medium were triturated with a flame-polished pipette, plated onto Falcon 3001 culture dishes, and stored in an incubator at $17^{\circ} \mathrm{C}$ until used.

We studied membrane currents of L-HCs with the whole-cell version of the patch-clamp method (Hamill et al., 1981). Just prior to an experiment $500 \mathrm{U} / \mathrm{ml}$ deoxyribonuclease was added to the dish for $5 \mathrm{~min}$. The cells then were rinsed with $2 \mathrm{ml}$ of Ringer's and the dish transferred to the stage of an Olympus IMT-2 inverted microscope. The composition of the Ringer's solution (in mM) was $\mathrm{NaCl}, 100 ; \mathrm{KCl}, 3.3 ; \mathrm{CaCl}_{2}$, $2 ; \mathrm{MgCl}_{2}, 1$; glucose, 10 ; and HEPES, 10. The $\mathrm{pH}$ was adjusted to 7.5 with $\mathrm{NaOH}$. The patch pipette solution (in mM) was $\mathrm{KCl}, 100 ; \mathrm{MgCl}_{2}$, 1; $\mathrm{CaCl}_{2}, 0.5$; EGTA, 5; HEPES, 10; and ATP, 2; pH 7.2. Whole-cell recordings were made using an Axoclamp $2 \mathrm{~A}$ amplifier (Axon Instruments, Foster City, CA) in the discontinuous single-electrode mode and pCLAMP software. The patch pipette had 5-10 M $\Omega$ resistance in Ringer's solution. Shifting the electrode from bath to intracellular solutions produced, maximally, 1-2 $\mathrm{mV}$ changes in apparent holding potential; these were ignored in data processing. With the electrode in the bath, any junction potential was set to zero with bridge balance and the capacitive decay to an applied square pulse minimized. After the electrode had sealed to the cell the bridge balance was adjusted again to zero current. The capacitive transient resulting from stepping the holding potential of the cell had a time constant of less than $1 \mathrm{msec}$; this transient decayed rapidly enough not to interfere with the neurotransmitter-gated currents we measured.

Drugs were applied either by perfusion from a gravity-fed pipette or, more frequently, by pressure pulses (Picospritzer, General Valve Corp., Fairfield, NJ) applied to a squirting pipette located close to the cell. All the data shown were obtained from brief (typically $200 \mathrm{msec}$ ) pulses of drug application. Drug-induced conductance changes were measured by superimposing $500 \mathrm{msec}, 20 \mathrm{mV}$, hyperpolarizing pulses $(1 / \mathrm{sec})$ on the holding potential. No correction was made for leakage currents.

\section{Results}

\section{Studies on isolated L-type horizontal cells}

We identified the glutamate receptor subclasses present in the membrane of horizontal cells by applying puffs of $\mathrm{L}$-glu, AMPA, quisqualate (quis), kainate (KA), and NMDA to isolated horizontal cells maintained in short-term culture. The Xenopus retina contains axon-bearing luminosity type horizontal cells (Witkovsky et al., 1988b) and axonless, chromaticity-type horizontal cells (Stone et al., 1990); these two subtypes were readily distinguished in the culture dish on the basis of marked differences in cell shape (Akopian and Witkovsky, 1994). The luminositytype cell (L-HC) has a round or oval profile, about $20 \mu \mathrm{m}$ in diameter or major axis, from which a few short processes emerge. Chromaticity-type neurons (C-HC) have markedly elongated profiles in which the perikaryal region merges with prominent long and stout dendrites. In this study only data from L-HCs are described. The voltage-clamp profiles provided an additional basis for identifying L-HCs (Akopian and Witkovsky, 1994), by revealing a prominent inward rectifier current that is characteristic of and unique to horizontal cells among retinal neurons (reviewed in Lasater, 1991)

\section{Currents induced by glutamate or its agonists}

From a holding potential of $-60 \mathrm{mV}$, L-glu, AMPA, quis, and $\mathrm{KA}$ each induced inward currents in the L-HC, associated with a conductance increase (Fig. $1 A$ ), as shown by the increased current elicited by $20 \mathrm{mV}, 0.5 \mathrm{sec}$, hyperpolarizing pulses superimposed on the holding potential. The agonist-gated currents showed reversal potentials slightly positive to zero $\mathrm{mV}$ (quis: $3.0 \pm 3.3 \mathrm{mV}, n=6$; KA: $6.1 \pm 6.6 \mathrm{mV}, n=6$; L-glu: $6.7 \pm$ $4.4 \mathrm{mV}, n=3$ ). The functions relating induced current amplitude to voltage were fit by straight lines, indicating that the 


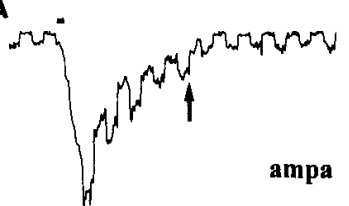
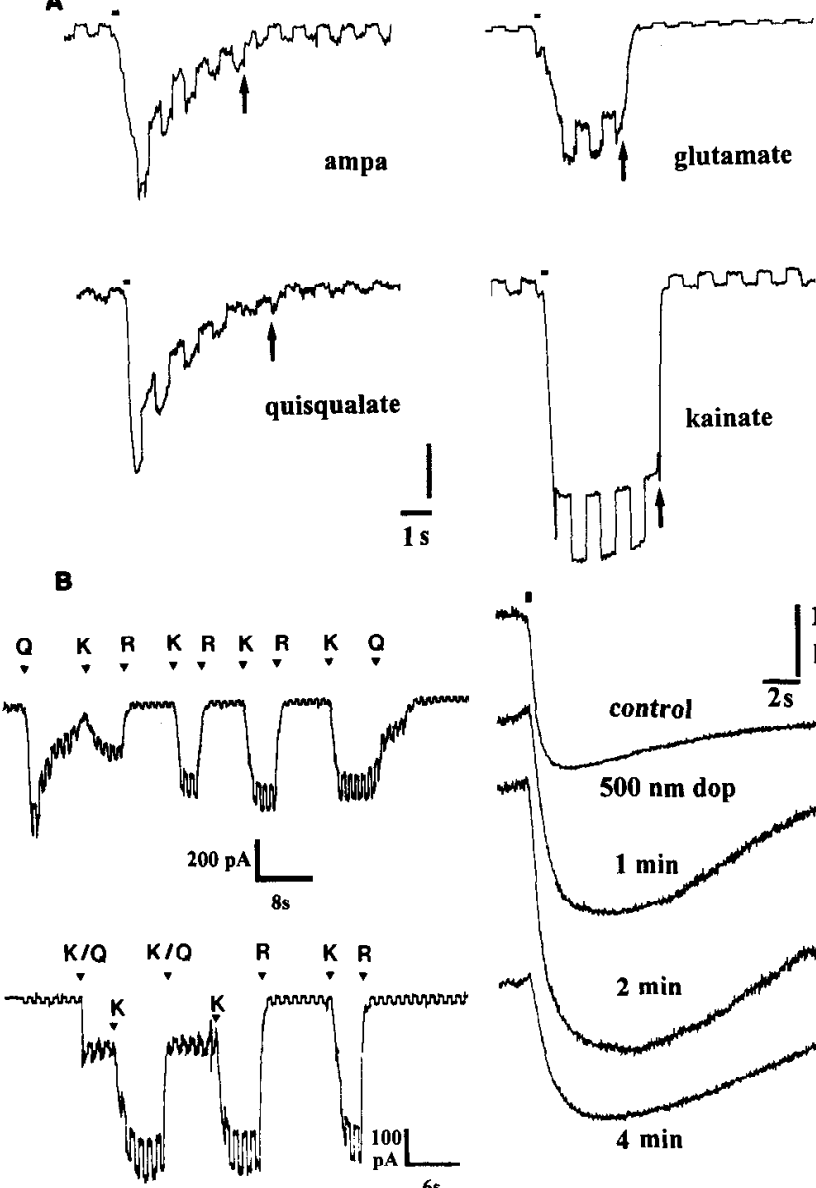

K R

.
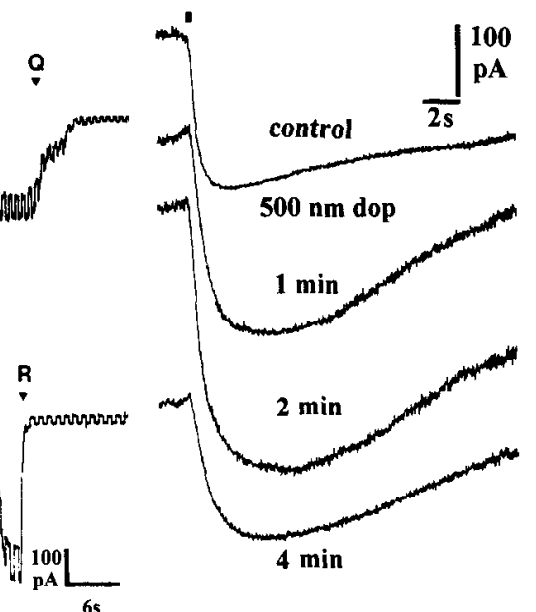

C
Figure 1. Responses of isolated L-HC to AMPA, glutamate, quisqualate, and kainate. L-HC were maintained in whole-cell patch configuration at a holding potential of $-60 \mathrm{mV}$. A train of $20 \mathrm{mV}, 500$ msec, hyperpolarizing pulses presented at $1 \mathrm{~Hz}$ was superimposed on the holding potential. AMPA $(25 \mu \mathrm{M})$, L-glu $(1 \mathrm{mM})$, KA $(50 \mu \mathrm{M})$, or quis $(20 \mu \mathrm{M})$ was pulsed onto the cell from a puffer pipette. The timing and pressure of the pulses were controlled by a Picospritzer device. The timing of the puff is indicated by a short horizontal bar above the current traces. $A$, All four agonists elicited inward (downward) currents associated with a conductance increase. AMPA and quis elicited desensitizing currents whereas glutamate and kainate evoked sustained currents. The return to baseline following agonist application was accelerated by a 1-2 sec wash with normal Ringer's solution (arrow) from a perfusion pipette. Amplitude calibration: $100 \mathrm{pA}$ for AMPA, quis, and glutamate; $300 \mathrm{pA}$ for kainate. $B$, Interaction of quisqualate and kainate in isolated L-HC. $K$, kainate, $50 \mu \mathrm{M} ; Q$, quisqualate, $20 \mu \mathrm{M} ; R$, Ringer's solution. Drug application and current monitoring were as for $A$. Arrowheads indicate approximate time of application of a $200 \mathrm{msec}$ puff of quis or $\mathrm{KA}$, or a 1 sec puff of Ringer's solution. Upper trace, At left, a puff of quisqualate induced a transient inward current. When a kainate puff was superimposed on the plateau phase of the quis response, it induced a smaller current than did the same kainate puff following a Ringer's wash. Successive puffs of kainate induced similar currents. When a puff of quis was superimposed on the kainate response, it evoked a smaller inward current than did quis alone (compare far left and far right records). Lower trace. One puffer pipette contained a mixture of $50 \mu \mathrm{M}$ kainate and $20 \mu \mathrm{M}$ quis; a second pipette contained $50 \mu \mathrm{M}$ kainate. The mixture induced a relatively small, sustained inward current associated with a modest increase in conductance. When $\mathrm{KA}$ alone was substituted, it evoked a larger response, but not as large as when it was applied following a Ringer's wash (response at right). $C$, Effect of dopamine on $\mathrm{L}-\mathrm{HC}$ responses to kainate. Top trace is the control. A $300 \mathrm{msec}$ puff of $50 \mu \mathrm{M} \mathrm{KA}$ elicited an inward current. In the absence of a Ringer's wash the current decayed relatively slowly. A $1.3 \mathrm{sec}$ puff of $0.5 \mu \mathrm{M}$ dopamine was applied between top two traces, and the test pulse of KA was applied each $30 \mathrm{sec}$ thereafter. At 1 and $2 \mathrm{~min}$, the KA-induced conductance gated by each agonist was independent of voltage. NMDA (10-100 $\mu \mathrm{M})$ was without effect on the L-HC, even in $\mathrm{Mg}$-free solution (not illustrated). The $\mathrm{KA} /$ quis antagonist CNQX, at $25 \mu \mathrm{M}$, completely blocked the inward current evoked by either quis, KA, or glutamate (not illustrated).

Kainate, applied from a puffer pipette, evoked a sustained inward current (Fig. 1 $A$ ). The dose-response curve for kainate rose steeply between 10 and $100 \mu \mathrm{M}$; the calculated $\mathrm{EC}_{50}$ of 68 $\mu \mathrm{M}$ was closely similar to that obtained by Zhou et al. (1993) for fish horizontal cells. Most cells tested were more sensitive to quis than to KA (thresholds in the range of $1-5 \mu \mathrm{M}$ quis), but the cell-to-cell data was too variable to yield a reliable doseresponse curve for quis. Puffs of AMPA or quisqualatc clicited transient responses (Fig. $1 \mathrm{~A}$ ), in which the peak decayed to 0.5 peak value in $351 \pm 79 \mathrm{msec}(n=7)$. When quis was applied via a relatively slow bath perfusion system only the smaller sustained component was observed. Because we did not employ a rapid perfusion system, the true time course of quis-induced desensitization could not be assessed. Glutamate usually elicited a sustained response resembling that evoked by kainate (Fig. $1 A$, lower record) but in some cases the L-glu current had a desensitizing component. The L-HC was 10-20 times less sensitive to glutamate than to kainate.

In drug-free Ringer's solution, the average input conductance of L-HCs was $0.99 \pm 0.09 \mathrm{nS}(n=20)$. This increased to 6.25 $\pm 0.59 \mathrm{nS}$ in the presence of 50-100 $\mu \mathrm{M} \mathrm{KA}(n=20)$, and 2.63 $\pm 0.35 \mathrm{nS}$ during exposure to $1-2 \mathrm{~mm}$ glutamate $(n=10)$. The conductance changes evoked by 20-50 $\mu \mathrm{M}$ quis were $6.25 \pm$ $0.78 \mathrm{nS}(n=5)$ for the peak of the transient component, dccreasing to $2.22 \pm 0.20 \mathrm{nS}(n=12)$ for the plateau phase of the response. Only a small number of experiments was done with AMPA; conductance changes evoked by 50-150 $\mu \mathrm{M}$ AMPA were in the same range as those elicited by $20-50 \mu \mathrm{M}$ quisqualate.

\section{Interaction of quis- and $K A$-induced currents}

Ishida and Neyton (1985) showed, in horizontal cells isolated from the goldfish retina, that quis reduced the current evoked by a constant dose of kainate. We obtained similar findings in L-HCs from the Xenopus retina; we noted also that the current elicited by a dose of either quis or $\mathrm{KA}$ was reduced by prior exposure to the other. Our protocol was first to obtain control responses by applying puffs of $\mathrm{KA}$ and quis separated by a rinse with drug-free Ringer's solution, then to overlap the pulses to observe the interaction (Fig. 1B). Application of two pulses either of KA or quis alone did not result in a desensitization to the second pulse of the pair. In contrast, when KA was applied in the presence of quis, the response to $\mathrm{KA}$ was markedly diminished by reference to the control value (Fig. $1 B$, upper trace, left side); in a parallel way, the response to quis was diminished when administered in the presence of KA (Fig. $1 B$, upper trace, right side). The trace in Figure $1 B$ illustrates that when quis and KA were combined in the same puffer pipette, the inward current elicited was less than that evoked by an identical puff of $\mathrm{KA}$ alone at the same concentration.

\section{Dopamine augments the inward current elicited by kainate}

Knapp and Dowling (1987) found, for cone-connected, teleost $\mathrm{HCs}$, that preexposure to 100-200 $\mu \mathrm{M}$ dopamine augmented the

current was larger than control, but recovered to control amplitude by $4 \mathrm{~min}$. 

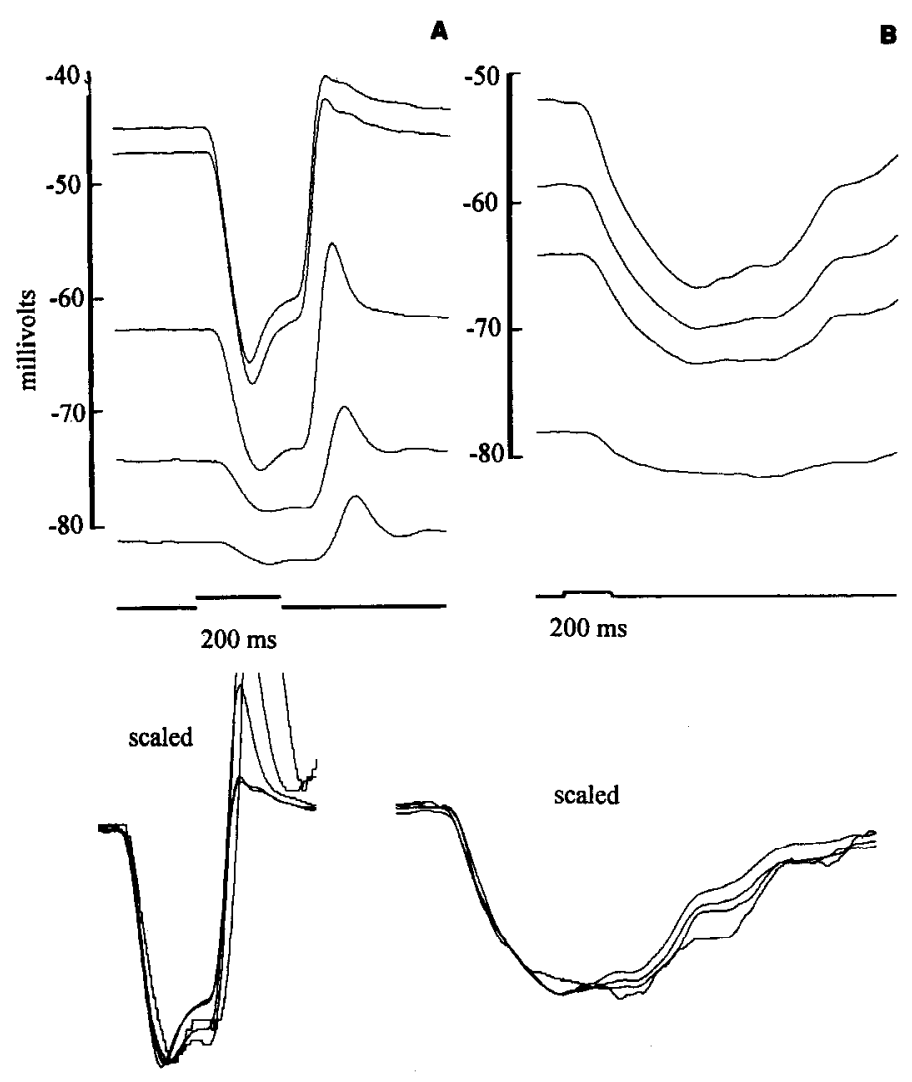

Figure 2. Effect of quinoxalinediones on the L-HC. $A$, Effect of superfusion with $80 \mu \mathrm{M} C N Q X /$ Ringer's on the membrane potential and light-evoked response of a photopic L-HC. Light flashes $(650 \mathrm{~nm}, 200$ msec, $\log Q=14.2,0.16 \mathrm{~Hz}$ ) were superimposed on a green background field $(527 \mathrm{~nm}, \log Q=12.8)$. The L-HC hyperpolarized progressively, associated with a reduced light-induced response, except for the depolarizing overshoot at light offset, which increased absolutely. Sample traces are positioned vertically (scale at left ) according to the dark membranc potential levels achieved just prior to the test stimulus (stimulus marker at bottom). Below, The traces were equated by a combination of vertical displacement and amplification. Note that the kinetics of the light-induced hyperpolarization were little altered by CNQX. $B$, Effect of quinoxalinediones on the scotopic L-HC. The same procedures shown in $A$ were utilized, except that no background field was imposed. Stimuli were $200 \mathrm{msec}, 527 \mathrm{~nm}, \log Q=9.93$. Sample traces show the progressive hyperpolarization and attenuation of the light-evoked response induced by exposure to $50 \mu \mathrm{M}$ CNQX/Ringer's (stimulus marker at bottom). Below, The traces were scaled and displaced vertically. CNQX had little effect on response kinetics.

response to a fixed dose of kainate. We repeated this experiment on Xenopus L-HCs, but employing lower dopamine concentrations $(0.20-20.0 \mu \mathrm{M}, n=11)$. In 4 of 11 cells, dopamine was without effect on the kainate response. In the remaining seven cells, exposure to $0.2-20 \mu \mathrm{M}$ dopamine increased the KA-induced current by $138 \pm 53 \%$ ([DA treated - control)/control] $\times 100$ ) within $2 \mathrm{~min}$. Figure $1 C$ illustrates the results from one such experiment, which shows that submicromolar doses of dopamine evoked increases in the response to kainate. Before exposure to dopamine, a $300 \mathrm{msec}$ puff of $50 \mu \mathrm{M}$ kainate elicited a peak inward current of $206 \mathrm{pA}$. The cell was exposed thereafter to $0.5 \mu \mathrm{M}$ dopamine for $1300 \mathrm{msec}$ and the same puff of KA applied at intervals of $30 \mathrm{sec}$. The peak KA response increased to $280 \mathrm{pA}$ after $1 \mathrm{~min}$, and $365 \mathrm{pA}$ after $2 \mathrm{~min}$ but recovered to control levels within $4 \mathrm{~min}$. To summarize, we found that the L-HC has ionotropic glutamate channels that can be acti- vated by L-glu, kainate, AMPA, or quisqualate. KA, and quisinduced currents are mutually antagonistic. Dopamine increases the KA-induced current on a slow time scale of seconds to minutes, consistent with its mediation by a second messenger (Knapp and Dowling, 1987; Knapp et al., 1990).

\section{Studies on eyecup preparations: blockage of glutamate receptors by $C N Q X$ or $D N Q X$}

The first question we posed in experiments on L-HCs in intact eyecups was whether both rod and cone inputs to the L-HC were mediated by glutamate. For these experiments, we took pains to ensure that the state of adaptation of the eye was well established. Our terminology is the traditional one from psychophysics (Le Grand, 1972): scotopic means the light-evoked response was driven by rods only, photopic, by cones only, and mesopic, by both rods and cones. Cone- and rod-initiated signals in L-HCs have been studied intensively in the Xenopus retina, where the two photoreceptor inputs are distinguished readily on the basis of waveform (Stone and Witkovsky, 1984) spectral and absolute sensitivities (Hassin and Witkovsky, 1983; Frumkes and Eysteinsson, 1987), range of response to flickering lights (Križaj and Witkovsky, 1993), and responses to dopamine or its specific D1 or D2 agonists (Witkovsky et al., 1988a, 1989; Križaj and Witkovsky, 1993). We utilized flashes of two test wavelengths, 527 and $650 \mathrm{~nm}$, to stimulate rod and cone inputs selectively (Witkovsky et al., 1989). When their relative intensities were adjusted for equal absorbance by rods, the scotopic L-HC flash or flicker responses were identical (Witkovsky and Shi, 1990; Križaj and Witkovsky, 1993), whereas the mesopic L-HC light response consisted of an early peak due to cone input and a later plateau generated by rod input.

When the eyecup was prepared in room light and subsequently exposed to a steady green background field $(527 \mathrm{~nm}$, flux $=\log$ 12.8 quanta $\mathrm{cm}^{-2} \mathrm{sec}^{-1}$ ) sufficient to saturate rods (Leibovic et al., 1987), we were able to test the effect of competitive antagonists of non-NMDA receptors, CNQX or DNQX, on conc to L-HC synaptic transfer. The action and effective doses of these two agents were identical with an $\mathrm{EC}_{50}$ of $40 \mu \mathrm{M}$. We utilized 50-100 $\mu \mathrm{M}$ of either CNQX or DNQX to obtain data of the sort illustrated in Figure $2 A$. For this light-adapted L-HC the membrane potential in darkness was $-32 \mathrm{mV}$, but it increased to $-45 \mathrm{mV}$ when the green background field was illuminated. The light-evoked response had a transient at light-off, visible in the predrug control record, which became larger as the cell hyperpolarized from $-45 \mathrm{mV}$ to $-60 \mathrm{mV}$, and was still larger than the control value at the most hyperpolarized level the cell achieved, $-82 \mathrm{mV}$. This overshoot is due to activation of voltage-dependent currents intrinsic to the L-HC that generate a larger voltage as the glutamate-dependent conductance falls (Akopian, Križaj, and Witkovsky, unpublished observations).

Selected light responses are illustrated in Figure $2 A$; the scale at the left indicates the membrane potential. When the same traces were vertically scaled to equate the peak light-evoked hyperpolarization, the kinetics of the hyperpolarizing portion of the light-evoked responses were seen to be little altered by exposure to CNQX (Fig. $2 A$, bottom). Identical results were obtained for 25 photopic L-HCs.

The effects of CNQX on responses obtained from a completely dark-adapted L-HC are shown in Figure $2 B$. The light-evoked responses of this cell were driven exclusively by rods, since red and green flashes matched for equal rod absorbance elicited identical waveforms (not illustrated). As noted for the cone- 
driven response (Fig. $2 A$ ), exposure to CNQX caused the cell to hyperpolarize while the light response was attenuated (Fig. $2 B$ ), but scaled responses had virtually identical waveforms, indicating no change in response kinetics (Fig. $2 B$, bottom). Similar results were obtained from 16 dark-adapted L-HCs, from which we conclude that both rod and cone inputs to the L-HC are mediated by ionotropic, non-NMDA glutamate receptors.

Blockage of the light-gated channels should bring the L-HC membrane potential to a value reflecting the remaining conductance(s). For the CNQX/DNQX data, when we graphed the fraction of control light-evoked response remaining against the absolute dark potential, regression lines drawn through the data for cone- or rod-driven L-HCs crossed the x-axis near -91 and $-98 \mathrm{mV}$, respectively (not illustrated), indicating that when the glutamate conductances are blocked the L-HC dark membrane potential is close to the equilibrium potential for potassium (Djamgoz and Laming, 1987). We note, however, that other inputs impinging on the $\mathrm{L}-\mathrm{HC}$, such as one dependent on glycine rclease from an interplexiform cell (Smiley and Basinger, 1988; Smiley and Yazulla, 1990), might have a reduced conductance if their activity depended on a glutamatergic input.

The data of Figure 2 indicate that CNQX/DNQX did not discriminate among cone- and rod-gated inputs to the $\mathrm{L}-\mathrm{HC}$, in that both are sensitive to these blockers. However exposure to quinoxalinediones did uncover an important interaction between rod and cone inputs to the L-HC that was only revealcd under mesopic conditions (Fig. $3 A$ ). When a mesopic eyecup was exposed to CNQX, the cone-driven response was diminished as the L-HC hyperpolarized, whereas the rod-driven response first became much larger and slower, then fell in amplitude as the cell hyperpolarized beyond about $-60 \mathrm{mV}$ (Fig. $3 A$ ). A similar growth of the rod input to the L-HC during inhibition of the cone input was effected by exposure to $2-4 \mathrm{~mm}$ kynurenate (not illustrated). When the mesopic responses elicited by $650 \mathrm{~nm}$ flashes were scaled to match the initial, conedriven peak, the growth in amplitude and slowed kinetics of the rod-driven component was apparent (Fig. $3 B$ ).

The results of CNQX administration on the rod input to a number of mesopic L-HCs are illustrated in Figure $3 C$. For easier visualization the data have been normalized along the scale of abscissae by setting the membrane potential value at which the maximum amplitude rod-driven input was achieved $=0 \mathrm{mV}$ (the true values were between -55 and $-65 \mathrm{mV}$ ). The data show that as the cell hyperpolarized from its predrug membrane potential (moving from right to left in Fig. $3 C$ ), the rodinitiated input first grew for the first approximately $15 \mathrm{mV}$ of hyperpolarization, and then fell as the cell continued to hyperpolarize. Evidently, suppression of cone-initiated input to the $\mathrm{L}-\mathrm{HC}$ resulted initially in a very substantial augmentation (up to fivefold) of rod input to the same L-HC.

The effects of exogenous L-glutamate, AMPA, or quisqualate on the $L-H C$ are dependent on adaptational state

Under photopic conditions, when the eyecup was superfused with Ringer's solution containing either L-glu $(n=7,5 \mathrm{mM})$, AMPA $(n=6,10-50 \mu \mathrm{M})$, or quis $(n=47,10-60 \mu \mathrm{M})$, the drug elicited a small (3-8 $\mathrm{mV})$ depolarization in the L-HC, associated with a transicnt reduction in the light-evoked response that recovered to between $50-100 \%$ of the predrug control within 1 min (Figs. $4 A, E ; 5 A, B$ ). The peak depolarization of the $\mathrm{L}-\mathrm{HC}$ was increased to $20-25 \mathrm{mV}$ when a saturating white light was
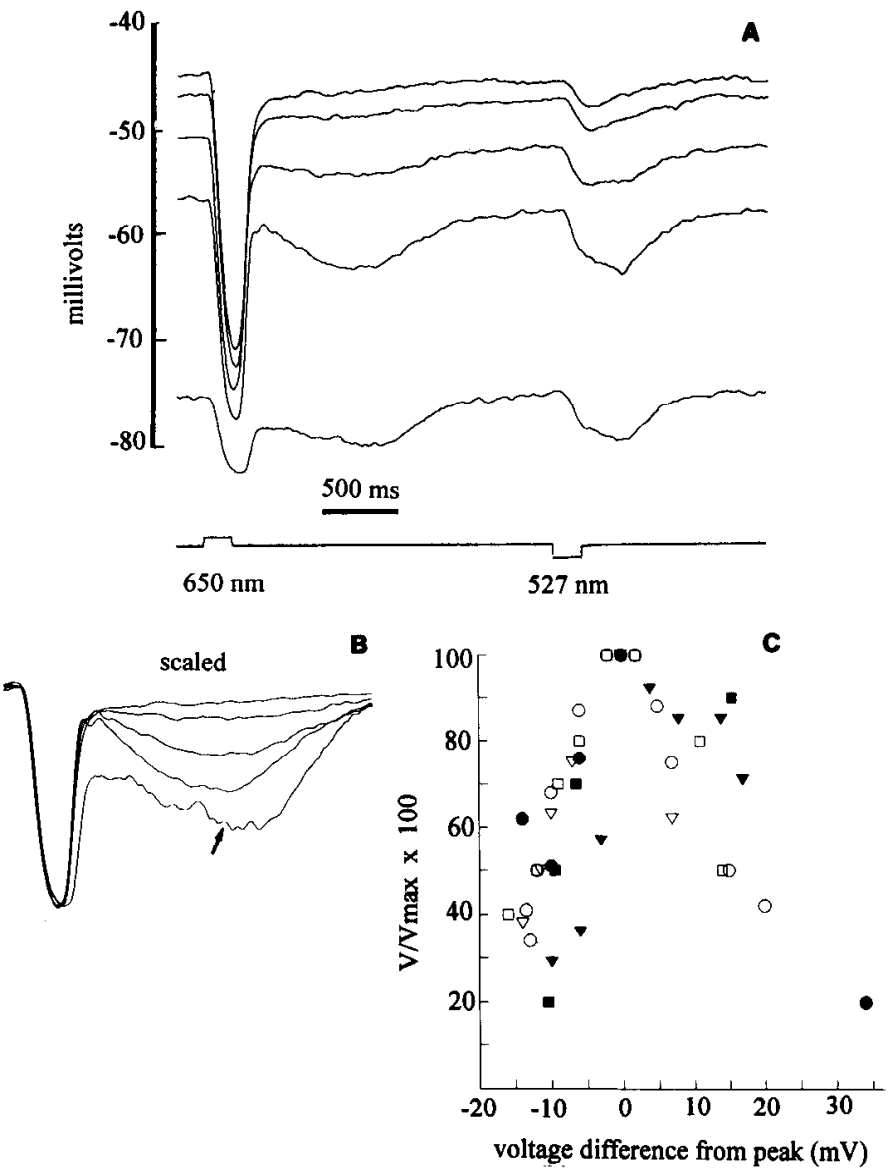

Figure 3. Effect of quinoxalinediones on the mesopic L-HC. $A$, The eyecup was stimulated alternately with $200 \mathrm{msec}$ flashes of 650 and 527 $\mathrm{nm}$ light (stimulus marker at bottom). Presentation of data is as for Figure 2. Note the growth and altered kinetics of the responses to 527 $\mathrm{nm}$ flashes as the cell hyperpolarized during administration of $50 \mu \mathrm{M}$ CNQX/Ringer's. $B$, The responses to the $650 \mathrm{~nm}$ flashes seen in $A$ were scaled by reference to the early peak attributable to cone input. This peak showed similar kinetics, whereas the secondary peak (arrow) due to rod input became both larger and slower during exposure to CNQX compared to the predrug response (top trace in $A$ ). $C$, Quinoxalinedioneinduced growth and decay of rod input to mesopic L-HC. Each symbol represents a different L-HC studied under mesopic conditions. The hyperpolarization obtained in response to $527 \mathrm{~nm}$ flashes is plotted against dark membrane potential level. Both axes are normalized. The ordinate is referenced to the largest light-induced hyperpolarization seen. The membrane potential at which this peak hyperpolarization was obtained $(-55$ to $-65 \mathrm{mV})$ is equated to 0 on the abscissa. Other membrane voltages are referenced to this point.

turned on that brought the membrane potential to between -60 and -80 and completely suppressed the light response. The depolarizing response, however, was still transient (Figs. $4 B$, $5 C$ ). The same effect seen in Figure $5 C$ was achieved when synaptic transmission to the L-HC was blocked by $100 \mu \mathrm{M}$ cadmium (not illustrated), indicating that a postsynaptic mechanism was involved. Figure $5 F$ illustrates that when CNQX (50 $\mu \mathrm{M})$ was administered together with $10 \mu \mathrm{M}$ quis, no depolarization was seen. Instead the cell hyperpolarized and the light response was markedly reduced, as expected for CNQX (Fig. 2).

Exposure to L-glu, AMPA or quis induced alterations in the waveform of the light-evoked responses of L-HCs. Under photopic conditions the rate of hyperpolarization was slowed and the onset of the repolarization phase at light offset was delayed (Fig. $4 F$ ). The rate of repolarization also was slowed slightly. 
L-glutamate
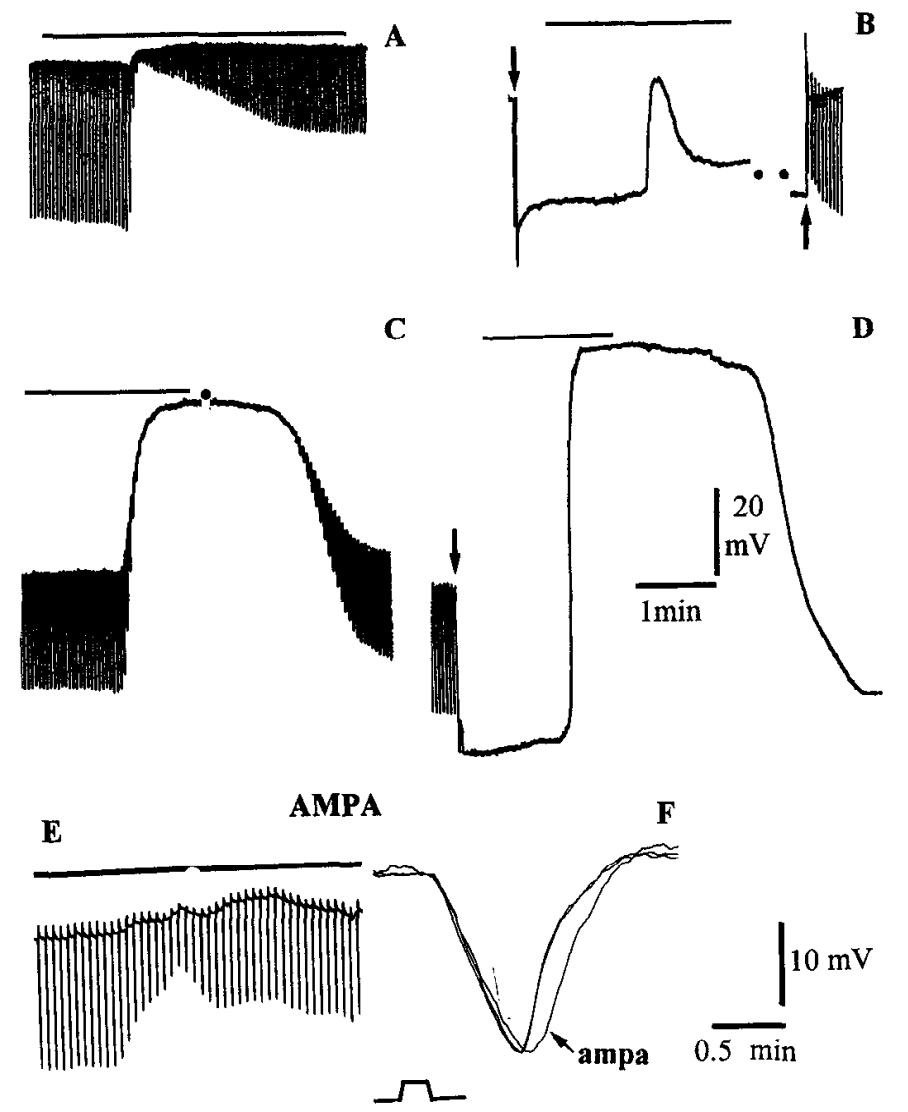

Figure 4. Responses of the L-HC to exogenous L-glu $(A-D, 5 \mathrm{~mm})$ and AMPA ( $E$ and $F, 25 \mu \mathrm{M}$ ) as a function of adaptational state. Periods of drug administration indicated by horizontal bars. $A$, and $B$, photopic state; $C$ and $D$, scotopic state. $A, 650 \mathrm{~nm}$ flashes $200 \mathrm{msec}$ long presented at $0.33 \mathrm{~Hz}$ on a steady $527 \mathrm{~nm}$ background field, $\log Q=14.2$. L-glu depolarized the $\mathrm{L}-\mathrm{HC} 3 \mathrm{mV}$ while light response transiently reduced to $<0.1$ control value, recovering to $\sim 0.55$ control within $2.5 \mathrm{~min}$. $B$, Illumination of strong white light (downward arrow) transiently hyperpolarized the L-HC to $-70 \mathrm{mV}$, relaxing to a plateau at $-61 \mathrm{mV}$. L-glu transiently depolarized the $\mathrm{L}-\mathrm{HC}$ to $-36 \mathrm{mV}$, recovering to $-55 \mathrm{mV}$ within $0.9 \mathrm{~min}$. After a $2.4 \mathrm{~min}$ wash in normal Ringer's, the L-HC recovered responses to flashes. White light turned off at upward arrow - - indicates $2 \mathrm{~min}$ break in record. $C$, Stimulation at $0.33 \mathrm{~Hz}$ by 200 msec flashes, $527 \mathrm{~nm}$ light, $\log Q=12.8$. No background light. During exposure to $\mathrm{L}$-glu the $\mathrm{L}-\mathrm{HC}$ depolarized to sustained potential of -1 $\mathrm{mV}$ while light response was abolished. Full recovery obtained following wash in normal Ringer's. O indicates 0.9 min break in record. $D$, Turning on white light (arrow) hyperpolarized L-HC to $-91 \mathrm{mV}$. L-glu then depolarized the cell to $0 \mathrm{mV}$. The $\mathrm{L}-\mathrm{HC}$ repolarized to $-80 \mathrm{mV}$ during normal Ringer's wash. $E$, Photopic retina stimulated at $0.33 \mathrm{~Hz}$ by 20 msec, $650 \mathrm{~nm}$ flashes, $\log Q=14.8$, in the presence of $527 \mathrm{~nm}$ background light, $\log Q=12.8$. AMPA transiently depolarized L-HC 3.6 $\mathrm{mV}$ while light-evoked response reduced to 0.4 initial value, thereafter recovering to 0.7 initial value. $F$, Superimposed light-evoked waveforms from same L-HC as in $E$. Control and recovery waveforms were essentially superimposable. AMPA (arrow) slowed repolarization phase of light-evoked response. Stimulus marker, $20 \mathrm{msec}$; waveforms were scaled vertically.

The kinetic changes seen under mesopic or scotopic conditions were similar but occurred to a lesser degree or in some cases were altogether absent. Recovery of the L-HC membrane potential during a wash in normal Ringer's solution following quis administration was associated with a return to control response kinetics (Fig. 4B).
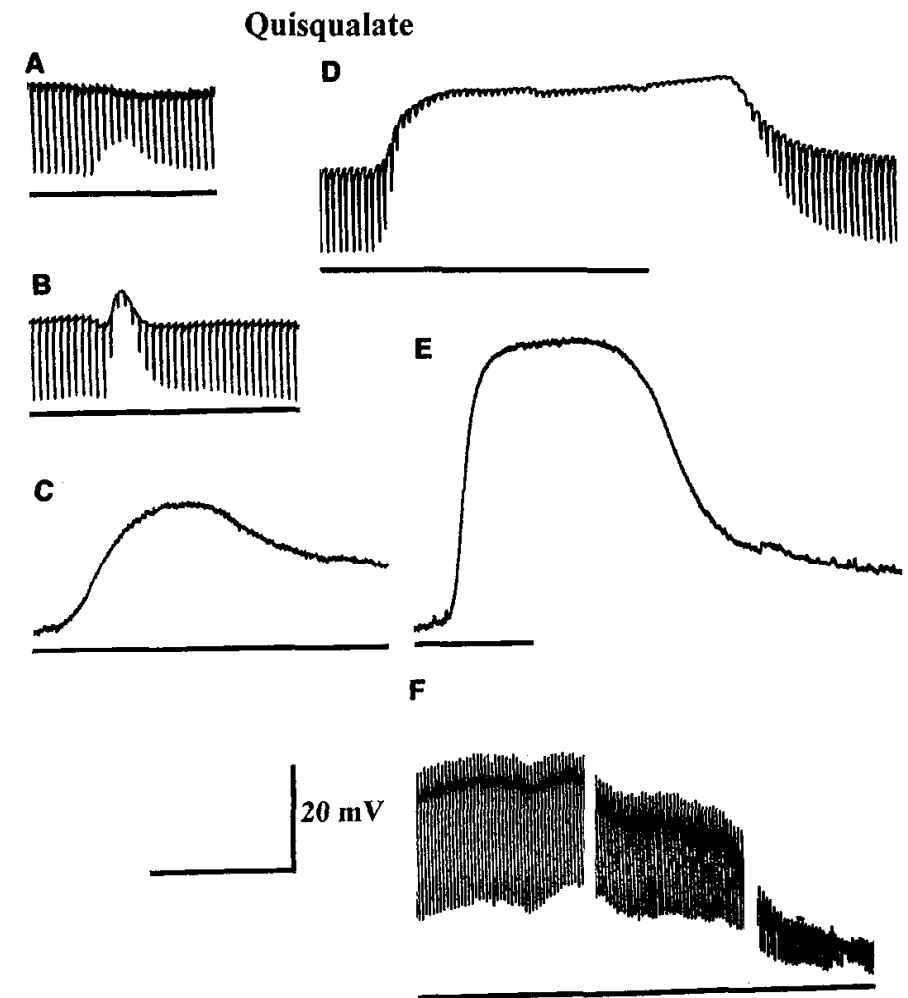

Figure 5. Responses of the L-HC to exogenous quisqualate; $10 \mu \mathrm{M}$ quis applied in every case for a period indicated by the horizontal bar. Time calibration: $1 \mathrm{~min}$ for $A-C, 2 \mathrm{~min}$ for $D$ and $E, 4 \mathrm{~min}$ for $F$. $A$ $C$, Quis-evoked responses from photopic L-HC. Test flash $650 \mathrm{~nm}, 200$ msec, $\log Q=14.2,0.33 \mathrm{~Hz}$. $A$, no background light; $B$, in the presencc of a $527 \mathrm{~nm}$ background, $\log Q=12.8 ; C$, in the presence of a saturating white light that brought the membrane potential to $-78 \mathrm{mV}$. Note that the quis-evoked response was transient under photopic conditions. $D$ and $E$, Scotopic state $(D)$ eyecup stimulated alternately with $650 / 527$ $\mathrm{nm}$ flashes balanced for equal rod absorbance $(E)$ in the presence of a saturating white light that brought membrane potential to $-77 \mathrm{mV}$. The quis-evoked response was large and sustained by reference to $A$ $C$. F, Photopic state, background light and test flashes as for $(B) 10 \mu \mathrm{M}$ quis was applied together with $50 \mu \mathrm{M} C \mathrm{CNQ}$. No quis-evoked depolarization was observed. Instead the membrane hyperpolarized and had a sharply reduced light response. At each of the breaks in the record a 2 min portion was removed.

The depolarizations evoked by L-glu, AMPA, or quis increased under mesopic conditions and were still larger in the scotopic state. Figures $4 C$ and $5 D$ illustrate $\mathrm{L}-\mathrm{HC}$ responses to L-glu and quis, respectively, under scotopic conditions. In Figure $5 D$ red and green light stimuli were balanced for equal rod absorbance. The fact that they generated equal responses indicates that this cell received input exclusively from rods. Compared to the photopic response obtained under the same conditions (Fig. $5 A$, no background field; $10 \mu \mathrm{M}$ quis), the scotopic response is larger (13.5 $\mathrm{mV}$ depolarization) and maintained, and is associated with a nearly complete loss of the light-evoked response. Similarly, L-glu (Fig. $4 C$ ) elicited a relatively large and maintained depolarization from a scotopic $\mathrm{L}-\mathrm{HC}$ together with a complete suppression of the light-evoked response.

Strong white light backgrounds hyperpolarized scotopic L-HCs to between -77 and $-93 \mathrm{mV}$, from which level L-glu (Fig. $4 D$ ) or quis (Fig. $5 E$ ) elicited sustained depolarizations of 50-90 $\mathrm{mV}$, bringing the $\mathrm{L}-\mathrm{HC}$ membrane close to the reversal potential for glutamate. Comparing Figurc 5, $C$ and $E$, the larger response obtained to quis under scotopic conditions cannot be attributed 
to a difference in the driving force, since the degree of membrane hyperpolarization attained before drug administration was virtually identical.

\section{DI dopamine ligands have opposite effects on quis- and $K A$ - evoked responses}

As illustrated earlier (Fig. 1C), dopamine, presumably acting through a D1 receptor (Knapp and Dowling, 1987) enhanced the $\mathrm{L}-\mathrm{HC}$ response to kainate. On the other hand responses to quis are smallest in the photopic state when dopamine concentrations reach their highest level (Witkovsky et al., 1993), suggesting that dopamine might inhibit responses to quis. To test this idea, we superfused light-adapted eyecups with $10 \mu \mathrm{M} \mathrm{SCH}$ 23390, a selective D1 dopamine antagonist, for 10-14 min prior to administration of a combination of $10 \mu \mathrm{M}$ quisqualate and $10 \mu \mathrm{M}$ SCH 23390 in Ringer's. Figure $6, A$ and $B$, shows responses to quis from the same L-HC under control conditions and after pretreatment with $\mathrm{SCH} 23390$. The response to quis was enhanced by prior exposure to SCH 23390 in that the response to quis became prolonged, the absolute value of the depolarization achieved increased, and the light response was attenuated to a much greater extent than with exposure to quis alone.

Figure $6 C$ provides a bar graph summary of the effects of quis and its modification by dopamine D1 ligands. The mean peak depolarization $\pm \mathrm{SE}$ elicited by $10 \mu \mathrm{M}$ quis was $7.4 \pm 1.2 \mathrm{mV}$ $(n=11)$ under photopic conditions, increasing to $16.5 \pm 3.9$ $\mathrm{mV}(n=6)$ under mesopic, and $27.1 \pm 2.2 \mathrm{mV}(n=7)$ under scotopic conditions (Fig. $6 \mathrm{~B}$, left). The photopic value was obtained with a background field illuminated that polarized the L-HC by $8-12 \mathrm{mV}$ whereas in the absence of a background field quis evoked no depolarization of the photopic L-HC. The righthand panel of Figure $6 \mathrm{C}$ shows that $\mathrm{SCH}$ increased the depolarizing action of quis under photopic conditions. All paired comparisons in Figure $6 \mathrm{C}$ are significant at the $95 \%$ confidence level or grcatcr.

We considered the possibility that exogenous quis depolarized the L-HC not by activating its glutamate receptors directly, but rather by driving some inner retinal pathway that affected the horizontal cell through a recurrent loop. The most plausible candidate transmitters for the final stage of the putative loop are glycine and dopamine, since interplexiform cells containing either of those two transmitters are known to exist in the Xenopus retina (Smiley and Basinger, 1988; Schütte and Witkovsky, 1991). To test this idea we repeated quis superfusion together with $10 \mu \mathrm{M}$ strychnine, which blocks the action of glycine on the L-HC (Stone and Witkovsky, 1984), and found that the quis response was slightly enhanced, not diminished as would be expected if quis were activating a glycine pathway (not illustrated). Second, the finding that the quis response is larger in the presence of the D1 dopamine antagonist, SCH 23390 (Fig. $6 B$ ), tends to rule out a primary role for dopamine in generating the response of the $\mathrm{L}-\mathrm{HC}$ to quis.

\section{Metabotropic glutamate ligands did not affect the $\mathrm{L}-\mathrm{HC}$ membrane potential or light-evoked response}

Quisqualate receptors can mediate either ionotropic responses or act through one or more second messenger systems at metabotropic quisqualate receptors (Baskys, 1992). Our data are consistent with quis acting only at ionotropic receptors. First, the quis effect was blocked completely by CNQX (Fig. $5 F$ ). Second, we found that addition of the metabotropic agonist,
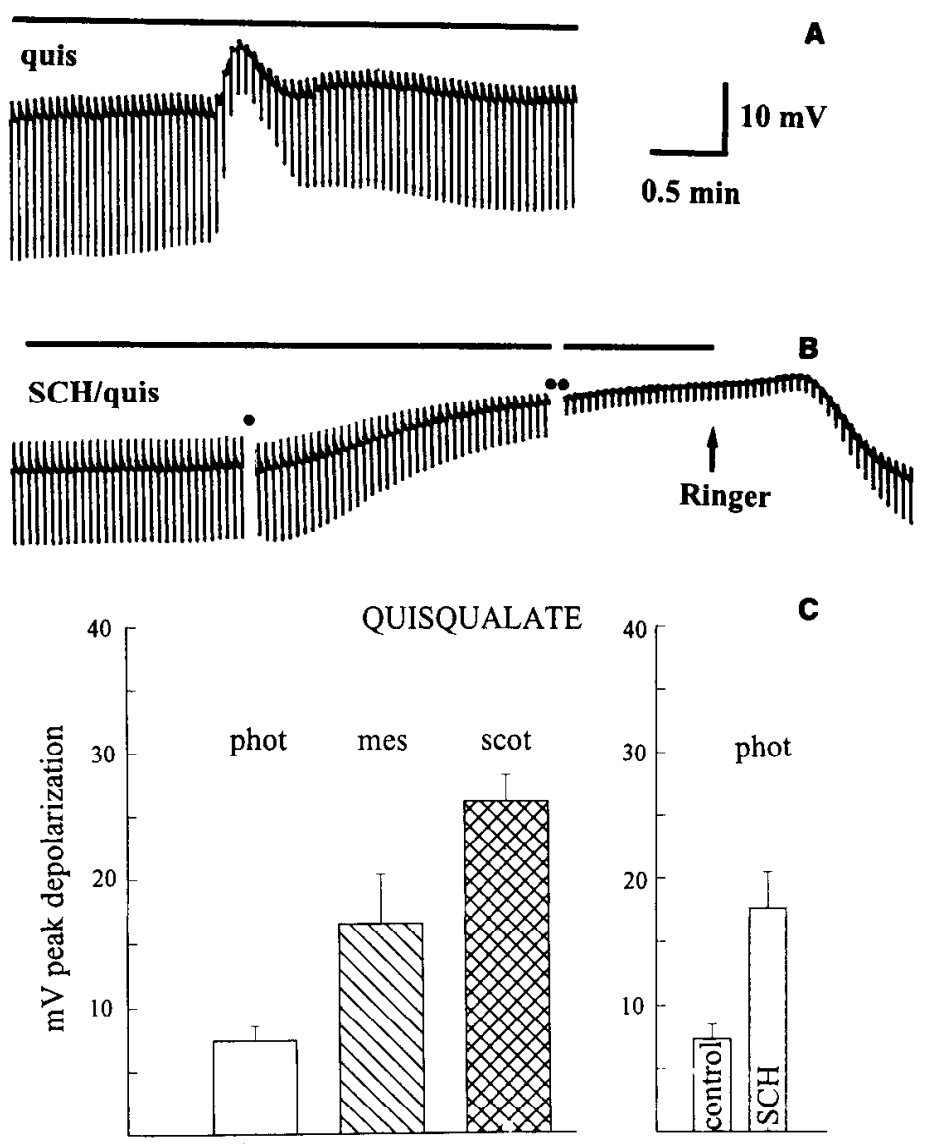

Figure 6. Effects of a D1 dopamine antagonist on the L-HC response to quis. $A$, Control trace under photopic conditions. Background light and stimuli were as for Figure 5. Horizontal bar shows time of quis (10 $\mu \mathrm{M})$ application. Note response to quis is relatively small and transient. $B$, Same cell as in $A$. The eyecup was superfused with Ringer's containing $10 \mu \mathrm{M} \mathrm{SCH} 23390(\mathrm{SCH})$ for $11 \mathrm{~min}$. Thereafter, $10 \mu \mathrm{M}$ quis $+10 \mu \mathrm{M}$ $\mathrm{SCH}$ were superfused. The L-cell [continuous trace with 0.7 (@) and 2.2 min (๑) breaks in the record) showed a larger and more sustained depolarization and a greater attenuation of the light response compared to that evoked by quis alone. $C$, Effects of quisqualate and dopamine D1 ligands on the L-HC. Left, Peak depolarization of dark membrane potential elicited by $10 \mu \mathrm{M}$ quis in photopic (phot), mesopic (mes), and scotopic (scot) states. Bars show means \pm 1 SE. Right, Peak depolarization evoked by quis alone (control) or following 10-14 min superfusion with Ringer's containing $10 \mu \mathrm{M}$ SCH 23390. Note that photopic data were obtained in the presence of a green background field. Pair differences were statistically significant at $95 \%$ confidence level.

trans-ACPD (25-50 $\mu \mathrm{M}, n=3)$ did not affect the membrane potential or the light-evoked response of the L-HC. Moreover addition of the metabotropic antagonist, AP-3 (25 $\mu \mathrm{M}, n=9)$, by itself evoked no change in the L-HC, nor was it able to antagonize the action of exogenous quis (not illustrated).

\section{Actions of kainate on the L-HC membrane potential and light-evoked response}

Eyecups in different adaptational states were superfused with KA/Ringer's, at doses ranging from 10 to $40 \mu \mathrm{M}(n=54)$. Like quis, KA elicited a depolarization, associated with an attenuation or a loss of the light response. However, unlike quis, the depolarization was sustained, whatever the adaptational state. One response to $20 \mu \mathrm{M} \mathrm{KA}$ under light-adapted conditions is illustrated in Figure $7 \mathrm{~A}$. The L-HC slowly depolarized by 29.2 $\mathrm{mV}$ and the light-evoked response was almost completely sup- 
$\mathbf{K A}$

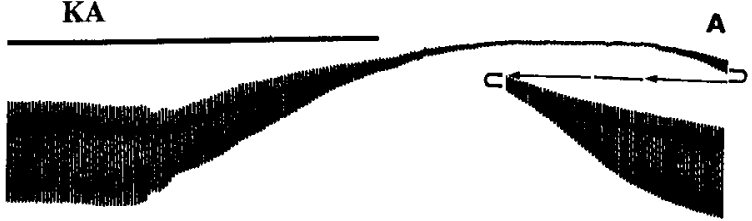

SKF/KA

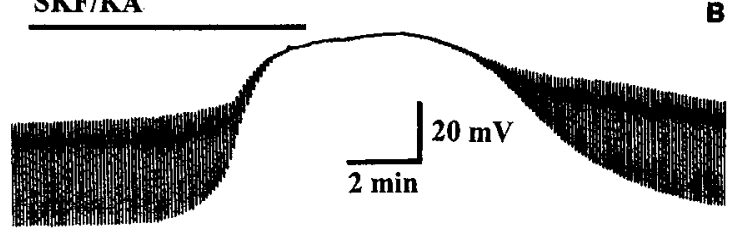

KAINATE
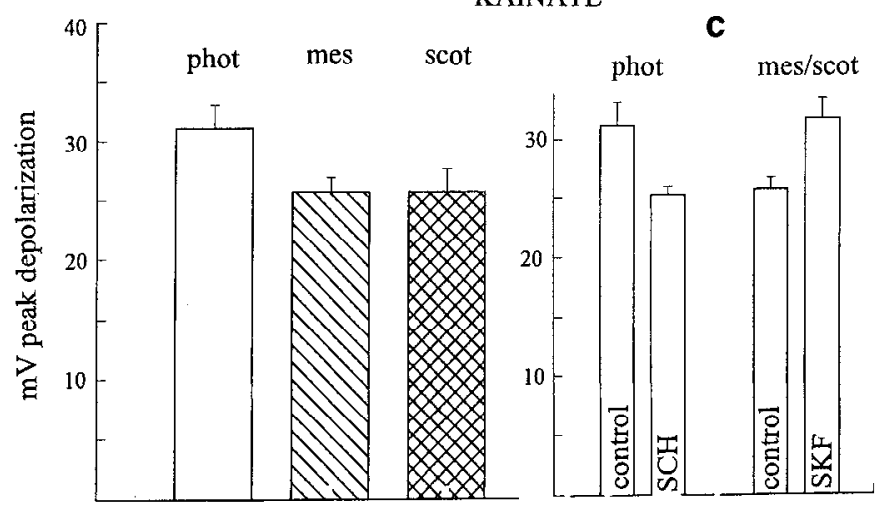

Figure 7. Effect of kainate on the L-HC. $A$, Photopic state. Stimulus conditions were as for Figure 5A. Horizontal bars indicate duration of exposure to $20 \mu \mathrm{M}$ kainate. Note slow depolarization and nearly complete suppression of light response. $B$, Same cell as in $A$. After $10 \mathrm{~min}$ exposure to $20 \mu \mathrm{M}$ SKF/Ringer's, the KA-evoked depolarization was faster and larger than in $A$ and the light response was abolished. C:Left, Peak depolarization elicited by $20 \mu \mathrm{M}$ kainate as a function of adaptational state. Differences between phot and either mes or scot data were statistically significant at $95 \%$ confidence level. Right, Modification of peak kainate-evoked depolarization by $20 \mu \mathrm{M} \mathrm{SCH}$ or $20 \mu \mathrm{M}$ SKF. Pair differences were statistically significant at $95 \%$ confidence level.

pressed. When the same cell was pretreated with $20 \mu \mathrm{M}$ SKF (D1 agonist) for $10 \mathrm{~min}$, exposure to $20 \mu \mathrm{M} \mathrm{KA}$ resulted in a more rapid depolarization that attained $37.7 \mathrm{mV}$ and a complete suppression of the light-evoked response (Fig. 7B). Neither the magnitude of the depolarization induced by KA nor the degree to which it attenuated the light response was as dramatically dependent on adaptational state as was found for quis. Nevertheless, there was a small but statistically significant effect, as illustrated in Figure $7 C$, left. KA-induced depolarizations were larger in light- adapted compared to dark-adapted eyes. The effects of dopamine DI ligands, moreover, were the opposite of those found for quis, that is, the KA-induced depolarization was enhanced by a D1 agonist and diminished by a D1 antagonist (Fig. $7 C$, right). Exposure to kainate resulted in a slowing of the light-evoked L-HC kinetics, nearly identical to that observed with quisqualate.

\section{Discussion}

\section{Responses of L-HCs to glutamate agonists}

The properties we noted for glutamate-, AMPA-, quis-, and KA-evoked currents: inward current from a negative holding potential, reversal potential near $0 \mathrm{mV}$, and a conductance in- crease, correspond to what is found generally in the CNS (reviewed in Mayer and Westbrook, 1987) and in particular for retinal horizontal cells in amphibian (Coleman et al., 1986, Yang and $\mathrm{Wu}, 1989$ ) and some fish retinas (Ishida and Neyton, 1985; O'Dell and Christensen, 1989a). The L-HC in Xenopus did not respond to NMDA, but a direct effect of NMDA on isolated L-HCs has been reported only for catfish horizontal cells (O'Dell and Christensen, 1989b).

In addition, we found that AMPA or quis elicited a transient current, whereas KA or glutamate, evoked a sustained current. Moreover, quis- and KA-induced currents were antagonistic. Ishida and Neyton (1985) reported that, in isolated horizontal cells from goldfish retina, quis inhibited the current elicited by $\mathrm{KA}$ in an uncompetitive manner, whereas O'Dell and Christensen (1989b) and Zhou et al. (1993) found that the interaction was competitive. Others have shown, however, that both competitive and noncompetitive interactions can occur in a single preparation, according to experimental conditions (Patneau and Mayer, 1991; Thio et al., 1991).

In agreement with earlier studies on fish horizontal cells (Knapp and Dowling, 1987) we found that KA-evoked currents were enhanced more than twofold by prior application of dopamine at micromolar concentrations. In the following sections we attempt to integrate these data on isolated L-HCs with the known properties of rod-cone interaction in the L-HC of the Xenopus retina.

\section{Organization of $L-H C$ contacts with rods and cones}

Amphibian second order neurons, including the L-HC, make direct synaptic contact with both rods and cones (Fain, 1975; Hanani and Vallerga, 1980; Hare et al., 1986; Witkovsky et al., 1988a,b). Cone contacts outnumber rod contacts with the L-HC by 2-3:1 (Witkovsky et al., 1988b) and the difference in number of L-HC glutamate receptors opposite cones and rods probably is much greater, since every cone has more synaptic ribbons than does each rod. Although patches of glutamate receptors opposite rods and cones are spatially segregated, the distance of separation can be less than $1 \mu \mathrm{m}$ (cf. Witkovsky and Powell, 1981, Fig. 11).

\section{Glutamate is the photoreceptor transmitter}

We assume that rods and cones utilize glutamate. Both isolated rods and cones release glutamate (Copenhagen and Jahr, 1989) and either rod or cone-connected HCs of fish retinas are sensitive to glutamate (Lasater and Dowling, 1982; Dowling et al., 1983). We found (Fig. 2) that quinoxalinediones, which are specific antagonists for non-NMDA, ionotropic glutamate channels (Honore et al., 1988), blocked rod and cone input to the Xenopus L-HC in a similar manner.

\section{L-HCs possess a single subtype of ionotropic glutamate receptor}

Kim and Miller (1991) argued, on the basis of pharmacological experiments, for separate and distinct glutamate receptors subserving rod and cone inputs. The preponderance of recent evidence in retina and other systems, however, favors the idea of a single AMPA/kainate receptor that can respond differentially to multiple glutamate agonists (Patneau and Mayer, 1991; Gasic and Hollmann, 1992). Cloning experiments show that gluR1gluR4 each responds to both quis and KA (Nakanishi et al., 1990), and the mRNAs for all these subtypes have been localized to the outer retina of mammals (Hamassaki-Britto et al., 1993). 
Also, the interaction of quis and $\mathrm{KA}$, which can be competitive (O'Dell and Christensen, 1989a), supports the idea of a single AMPA/KA receptor. Thus, for the purposes of this discussion we assume that the Xenopus L-HC has a single class of nonNMDA ionotropic glutamate receptor.

\section{The ionotropic glutamate receptor is modifiable}

The effect of quinoxalinediones under mesopic conditions (Fig. 3) reveals that cone input exerts a tonic inhibition on rod to L-HC communication, which changes both the gain and kinetics of rod synaptic transfer. This inhibition must occur at the postsynaptic membrane where CNQX binds. Because rod input to the L-HC increases while cone input falls, and yet both inputs are presumed to be mediated by a single glutamate receptor class, we conclude that the glutamate receptor patches opposite rods and cones are (1) nonindependent, and (2) capable of existing in different functional states.

Further evidence for the modifiability of the glutamate receptor comcs from the different responses obtained to L-glu, AMPA or quis in light- and dark-adapted eyes. Under photopic conditions the responses to all three agents were small and transient; but when the dark-adapted eye was exposed to the same agents at the same doses, the responses were large and sustained. Secondly, a D1 dopamine antagonist potentiated the response to quis under photopic conditions, whereas KA-evoked responses were enhanced by a D1 dopamine agonist, but reduced by a D1 dopamine antagonist.

There is good evidence that the desensitizing response evoked by L-glutamate, AMPA or quis involves a fall in channel gating from a high-conductance to a low-conductance state (Sommer et al., 1990; Mayer et al., 1991; Raman and Trussell, 1992). The response to kainate, in contrast, is nondesensitizing. It is plausible that the adaptation-induced changes we observe in the response of the L-HC to L-glutamate, AMPA, or quis involve conformational changes in the glutamate channel that affect the propensity to desensitize and/or to bind one or another agonist. There is an apparent contradiction, however, in our findings that points out a lack of understanding of glutamate receptor properties in the L-HC. On the one hand, kainate responses are largest in photopic eyecups. Kainate responses are enhanced by dopamine, whose levels also are largest in the photopic state (Witkovsky et al., 1993). Thus, one might conclude (Kim and Miller, 1991) that glutamate released by cones evokes kainatetype responses in the $\mathrm{L}-\mathrm{HC}$, that is, that the glutamate receptors are in a nondesensitized state (Patneau and Mayer, 1991). On the other hand exogenous application of L-glutamate results in a small and transient depolarization in photopic L-HCs, suggesting that glutamate receptors are mainly desensitized. Of course other factors dependent on adaptational state, such as the rate of transmitter release by cones, also affect the light response of the L-HC. It remains for future work to sort them out.

Parenthetically, we think that the changes in response kinetics induced by exogenous L-glu, AMPA (Fig. 4B), quis or kainate are not evidence for an underlying mechanism of physiological significance. As the agonist reaches the synapse it will bind to glutamate receptors, but when light shuts off the release of endogenous glutamate, the presence of a glutamatc analog that is not removed by the uptake system continues to keep some channels open, thereby slowing the rate of membrane hyperpolarization.

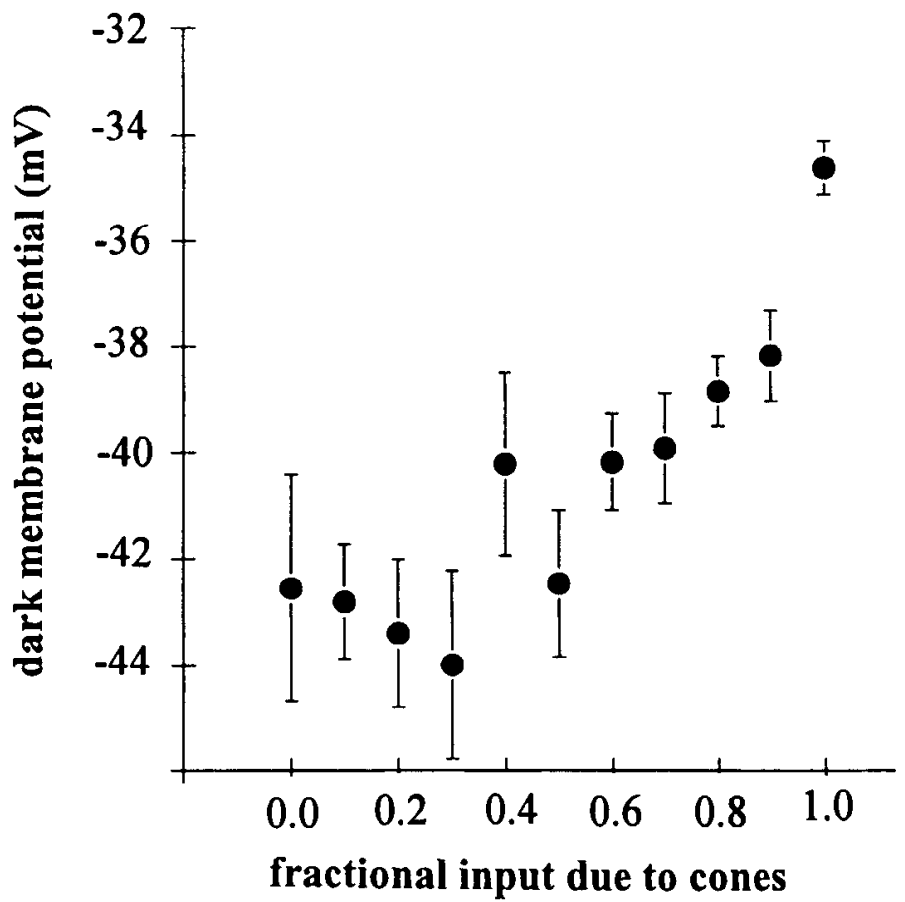

Figure 8. Relation between cone input and dark membrane potential in the L-HC. A sample of $300 \mathrm{~L}-\mathrm{HC}$ was obtained from drug-free experiments. The fractional input due to cones was assessed by subtracting the waveform evoked by a $527 \mathrm{~nm}$ flash from that evoked by a $650 \mathrm{~nm}$ flash when the flash intensities were equated for equal rod absorbance (cf. Fig. 1 of Witkovsky and Shi, 1990). A value of 1.0 on the scale of abscissae means $100 \%$ cone input, a value of 0 means $100 \%$ rod input. Intermediate values were grouped to the nearest tenth. The dark membrane potential of the L-HC just prior to the test flashes is plotted on the scale of ordinates. Data points are means $\pm 1 \mathrm{SE}$.

\section{The circuit underlying a shunt of rod-initiated signals by cones}

In addition to the postulated alteration of glutamate receptors discussed above, rod and cone inputs can interact via a shunt. The spatial separation of glutamate receptor patches mediating rod- and cone-HC synaptic transfer means that rod and cone batteries lie in parallel, and as a consequence, in the dark the membranc potential of the L-HC should be most depolarized when glutamate release is highest and/or its action at the postsynaptic membrane is most potent. This follows from the fact that the equilibrium potential for the glutamate-gated channel is near $0 \mathrm{mV}$ : the higher the conductance of this channel, the greater its relative weight in controlling the membrane potential. Our impression was that L-HCs are most depolarized under light-adapted conditions, but to put this to a more quantitative test we assembled a sample of 300 Xenopus L-HCs taken from experiments without drug treatments. The response waveform was examined by the method of Witkovsky and Shi (1990) to estimate the fraction of cone input from the relative responses to red and green flashes whose intensities were matched for rods. Figure 8 reveals an approximately exponential relation between fractional cone input (Witkovsky and Shi, 1990) and membrane potential. The exponential function is consistent with a simple analog circuit consisting of two or more batteries in parallel, all but one of which has a fixed, relatively low conductance (e.g., a potassium battery) and the other has a variable conductance (cf. Fig. 14 of Witkovsky et al., 1989). 


\section{A schematic of rod-cone interaction}

To summarize our schematic: shunting plays a role in reducing rod input to the L-HC (Witkovsky et al., 1989), but it alone cannot account for the large changes in both the gain and kinetics of rod to L-HC communication seen when cone to L-HC synaptic transfer is blocked by CNQX (Fig. 3). We postulate that cross talk exists between patches of modifiable glutamate receptors in the L-HC opposite rod and cone bases. The mechanism of the putative cross-talk is unknown but it appears to require a diffusible messenger, such as cAMP. There is good evidence that dopamine acts through a D1 receptor to increase cAMP levels (Watling et al., 1980), which in turn participate in the phosphorylation of the glutamate receptor or a closely related protein (Liman et al., 1989). The functional consequence is to increase the fraction of time the glutamate channel spcnds in the open state (Knapp et al., 1990). Dopamine may also function to prevent or reduce desensitization of the glutamate receptor (Kruse and Schmidt, 1993). Whatever its underlying basis such cross talk is plausible, in that all the known types of glutamate receptor can be coupled to second messenger systems (Smart, 1989).

It is worth noting that the changes that occur normally in dark-adaptation are like those brought about when cone input is reduced or blocked by drugs. That is, rod input to L-HCs is larger and has slower kinetics in the scotopic state than under mesopic conditions, indicating that an increase in the gain of rod to L-HC synaptic transfer during dark adaptation is associated with a change in kinetics. We have not dealt in this study with the reciprocal pathway whereby rods inhibit transmission from cones to second order cells (Frumkes and Eysteinsson, 1987) but it may also involve cross-talk between glutamate receptors. Given the dearth of specific information, at present the primary goal of our scheme must be heuristic-to focus attention on the possibility that regulation of glutamate receptors in the horizontal cell may be an important factor in light and dark adaptation.

\section{References}

Akopian A, Witkovsky P (1994) Modulation of transient outward potassium current by GTP, calcium and glutamate in horizontal cells of the Xenopus retina. J Neurophysiol, in press.

Alexander KR, Fishman GA (1984) Rod-cone interaction in flicker perimetry. Br J Ophthalmol 68:303-309.

Ayoub GS, Korenbrot JI, Copenhagen DR (1989) Release of endogenous glutamate from isolated cone photoreceptors of the lizard. Neurosci Res [Suppl] 10:S47-S56.

Baskys A (1992) Metabotropic receptor and 'slow' excitatory actions of glutamate agonists in the hippocampus. Trends Neurosci 15:9296.

Coleman PA, Massey SC, Miller RF (1986) Kynurenic acid distinguishes kainate and quisqualate receptors in the vertebrate retina. Brain Res 381:172-175.

Copenhagen DR, Jahr CE (1989) Release of endogenous excitatory amino acids from turtle photoreceptors. Nature 341:536-539.

Djamgoz MBA, Laming, PJ (1987) Micro-electrode measurements and functional aspects of chloride activity in cyprinid fish retina: extracellular activity and intracellular activities of L- and C-type horizontal cells. Vision Res 27:1481-1489.

Dowling JE, Ripps H (1972) Adaptation in skate photoreceptors. J Gen Physiol 60:698-719.

Dowling JE, Lasater EM, VanBuskirk R, Watling KJ (1983) Pharmacological properties of isolated fish horizontal cells. Vision Res 23: $421-432$.

Eysteinsson T, Frumkes TE (1989) Physiological and pharmacologic analysis of suppressive rod-cone in Necturus retina. J Neurophysiol 61:866-877.
Fain GL (1975) Interactions of rod and cone signals in the mudpuppy retina. J Physiol (Lond) 252:735-769.

Frumkes TE, Eysteinsson T (1987) Suppressive rod-cone interaction in distal vertebrate retina: intracellular records from Xenopus and Necturus. J Neurophysiol 57:136i-1382.

Gasic GP, Hollman M (1992) Molecular neurobiology of glutamate receptors. Annu Rev Physiol 54:507-536.

Hamassaki-Britto DE, Hermans-Borgmeyer I, Heinemann S, Hughes TE (1993) Expression of glutamate receptorgenes in the mammalian retina: the localization of GluR 1 through GluR7 mRNAs. J Neurosci 13:1888-1898.

Hamill OP, Marty A, Neher E, Sakmann B, Sigworth FJ (1981) Improved patch clamp techniques for high resolution current recording from cells and cell-free membrane patches. Pfluegers Arch 391:85100.

Hanani M, Vallerga S (1980) Rod and cone signals in the horizontal cells of the tiger salamander retina. J Physiol (Lond) 298:397-405.

Hare WA, Lowe JS, Owen G (1986) Morphology of physiologically identified bipolar cells in the retina of the tiger salamander, Ambystoma tigrinum. J Comp Neurol 252:130-138.

Hassin G, Witkovsky P (1983) Intracellular recording from identified photoreceptors and horizontal cells of the Xenopus retina. Vision Res 23:921-931.

Honoré T (1991) Quisqualate/AMPA-preferring configurations of nonNMDA receptors. In: Excitatory amino acids and synaptic function (Wheal H, Thomson A, eds), pp 55-67. New York: Academic.

Ishida AT, Neyton J (1985) Quisqualate and L-glutamate inhibit retinal horizontal cell responses to kainate. Proc Natl Acad Sci USA 82: 1837-1841.

Kim HG, Miller RF (1991) Rods and cones activate different excitatory amino acid receptors on the mudpuppy retinal horizontal cell. Brain Res 538:141-146.

Knapp AG, Dowling JE (1987) Dopamine enhances excitatory amino acid-gated conductances in retinal horizontal cells. Nature 325:437439.

Knapp AG, Schmidt KF, Dowling JE (1990) Dopamine modulates the kinetics of ion channels gated by excitatory amino acids in retinal horizontal cells. Proc Natl Acad Sci USA 87:767-771.

Križaj D, Witkovsky P (1993) Effects of submicromolar concentrations of dopamine on photoreceptor to horizontal cell communication. Brain Res 627:122-128.

Kruse M, Schmidt K-F (1993) Studies on the dopamine-dependent modulation of amino acid-gated currents in cone horizontal cells of the perch (Perca fluviatilis). Vision Res 33:2031-2042.

Lasater EM (1991) Membrane properties of distal retinal neurons. Prog Ret Res 11:215-246.

Lasater EM, Dowling JE (1982) Carp horizontal cells in culture respond selectively to L-glutamate and its agonists. Proc Natl Acad Sci USA 79:936-940.

Le Grand Y (1972) Spectral luminosity. In: Handbook of sensory physiology, Vol VII/4 (Jameson D, Hurvich LM, eds), pp 413-433. Berlin: Springer.

Leibovic KN, Dowling JE, Kim YY (1987) Background and bleaching equivalence in steady-state adaptation of vertebrate rods J Neurosci 7:1056-1063.

Liman ER, Knapp AG, Dowling JE (1989) Enhancement of kainategated currents in retinal horizontal cells by cyclic AMP-dependent protein kinase. Brain Res 481:399-402.

Marc RE, Liu W-LS, Kalloniatis M, Raiguel SF, Van Haesendonck E (1990) Patterns of glutamate immunoreactivity in the goldfish retina. J Neurosci 10:4006-4034.

Massey SC (1989) Cell types using glutamate as a neurotransmitter in the vertebrate retina. Prog Ret Res 399-425.

Mayer ML, Westbrook GL (1987) The physiology of excitatory amino acids in the vertebrate central nervous system. Prog Neurobiol 28: 197-276.

Mayer ML, Vyklicky L Jr, Benveniste M, Patneau DL, Williamson L (1991) Desensitization at NMDA and AMPA-kainate receptors. In: Excitatory amino acids and synaptic function (Wheal $\mathrm{H}$, Thomson A, eds), pp 123-140. New York: Academic.

Nakanishi N, Schneider NA, $\Lambda$ xel R (1990) $\Lambda$ family of glutamate receptor genes: evidence for the formation of heteromultimeric receptors with distinct channel properties. Neuron 5:569-581.

O'Dell TJ (1989) Pharmacological characterization of voltage-clamped 
catfish rod horizontal cell responses to kainic acid. Brain Res 477: 118-125.

O'Dell TJ, Christensen BN (1989a) A voltage-clamp study of isolated stingray horizontal cell non-NMDA excitatory amino acid receptors J Neurophysiol 61:162-172.

O'Dell TJ, Christensen BN (1989b) Horizontal cells isolated from catfish retina contain two types of excitatory amino acid receptors. J Neurophysiol 61:1097-1109.

Patneau DK, Mayer ML (1991) Kinetic analysis of interactions between kainate and AMPA: evidence for activation of a single receptor in mouse hippocampal neurons. Neuron 6:785-798.

Raman IM, Trussell LO (1992) The kinetics of the response to glutamate and kainate in neurons of the avian cochlear nucleus. Neuron 9:173-186.

Schnapf J, Copenhagen D (1982) Differences in kinetics of rod and cone synaptic transmission. Nature 296:862-864.

Schütte M, Witkovsky P (1991) Dopaminergic interplexiform cells and centrifugal fibers in the Xenopus retina. J Neurocytol 20:195207.

Smart TG (1989) Excitatory amino acids: the involvement of second messengers in the signal transduction process. Cell Mol Neurobiol 9:193-206.

Smiley JF, Basinger S (1988) Somatostatin-like immunoreactivity and glycine high-affinity uptake colocalize to an interplexiform cell of the Xenopus laevis retina. J Comp Neurol 274:608-618.

Smiley JF, Yazulla S (1990) Glycinergic contacts in the outer plexiform layers of the Xenopus laevis retina characterized by antibodies to glycine, GABA and glycine receptors. J Comp Neurol 299:375-388.

Sommer B, Keinanen K, Verdoorn TA, Wisden W, Burnashev N, Herb A, Kohler M, Takagi T, Sakmann B, Seeburg PH (1990) Flip and flop: a cell-specific functional switch in glutamate-operated channels of the CNS. Science 249:1580-1585.

Stone S, Witkovsky P (1984) The actions of $\gamma$-aminobutyric acid, glycine and their antagonists upon horizontal cells of the Xenopus retina. J Physiol (Lond) 353:249-264.

Stone S, Witkovsky P, Schütte M (1990) A chromatic horizontal cell in the Xenopus retina: intracellular staining and synaptic pharmacology. J Neurophysiol 64:1683-1694.
Takahashi K-I, Copenhagen DR (1992) APB suppresses synaptic input to retinal horizontal cells in fish: a direct action on horizontal cells modulated by intracellular pH. J Neurophysiol 67:1633-1642.

Thio LL, Clifford DB, Zorumski CF (1991) Characterization of quisqualate receptor desensitization in cultured postnatal rat hippocampal neurons. J Neurosci 11:3430-3441.

Watling KJ, Dowling JE, Iversen LL (1980) Dopaminergic mechanisms in the carp retina: effects of dopamine, $\mathrm{K}^{+}$and light on cyclic AMP synthesis. In: Neurochemistry of the retina (Bajan N, Lolley R, eds), pp 519-537. Oxford: Pergamon.

Witkovsky P, Powell CC (1981) Synapse formation and modification between distal retinal neurons in larval and juvenile Xenopus. Proc R Soc Lond [Biol] 211:373-389.

Witkovsky P, Shi X-P (1990) Slow light and dark adaptation of horizontal cells in the Xenopus retina: a role for endogenous dopamine. Vis Neurosci 5:405-413.

Witkovsky P, Stone S, Besharse J (1988a) Dopamine modifies the balance of rod and cone inputs to horizontal cells of the Xenopus retina. Brain Res 449:332-336.

Witkovsky P, Stone S, MacDonald ED (1988b) Morphology and synaptic connections of HRP-filled axon-bearing horizontal cells in the Xenopus retina. J Comp Neurol 275:29-38.

Witkovsky P, Stone S, Tranchina D (1989) Photoreceptor to horizontal cell synaptic transfer in the Xenopus retina: modulation by dopamine ligands and a circuit model for interactions of rod and cone inputs. J Neurophysiol 62:864-881.

Witkovsky P, Nicholson C, Rice ME, Bohmaker K, Meller E (1993) Extracellular dopamine concentration in the retina of the clawed frog, Xenopus laevis. Proc Natl Acad Sci USA 90:5667-5671.

Yang X-L, Wu SM (1989) Effects of CNQX, APB, PDA, and kynurenate on horizontal cells of the tiger salamander retina. Vis Neurosci 3:207-212.

Zhou ZJ, Fain GL, Dowling JE (1993) The excitatory and inhibitory amino acid receptors on horizontal cells isolated from the white perch retina. J Neurophysiol 70:8-19. 